\title{
Exercise-induced up-regulation of MMP-I and IL-8 genes in endurance horses
}

\author{
Katia Cappelli*†, Michela Felicetti ${ }^{\dagger}$, Stefano Capomaccio ${ }^{\dagger}$, \\ Camillo Pieramati, Maurizio Silvestrelli and Andrea Verini-Supplizi
}

Address: Pathology, Diagnostic and Veterinary Clinic Department, University of Perugia, Via San Costanzo 4, 06126 Perugia, Italy

Email: Katia Cappelli* - katia.cappelli@unipg.it; Michela Felicetti - michelafelicetti@yahoo.it; Stefano Capomaccio - capemaster@gmail.com; Camillo Pieramati - camillo.pieramati@unipg.it; Maurizio Silvestrelli - maurizio.silvestrelli@unipg.it; Andrea Verini-

Supplizi - andrea.verini@unipg.it

* Corresponding author †Equal contributors

Published: 24 June 2009

BMC Physiology 2009, 9:12 doi:10.1 186/1472-6793-9-12
Received: 17 November 2008

Accepted: 24 June 2009

This article is available from: http://www.biomedcentral.com/1472-6793/9/12

() 2009 Cappelli et al; licensee BioMed Central Ltd.

This is an Open Access article distributed under the terms of the Creative Commons Attribution License (http://creativecommons.org/licenses/by/2.0), which permits unrestricted use, distribution, and reproduction in any medium, provided the original work is properly cited.

\begin{abstract}
Background: The stress response is a critical factor in the training of equine athletes; it is important for performance and for protection of the animal against physio-pathological disorders.

In this study, the molecular mechanisms involved in the response to acute and strenuous exercise were investigated using peripheral blood mononuclear cells (PBMCs).

Results: Quantitative real-time PCR (qRT-PCR) was used to detect modifications in transcription levels of the genes for matrix metalloproteinase-I (MMP-I) and interleukin 8 (IL-8), which were derived from previous genome-wide expression analysis. Significant up-regulation of these two genes was found in 10 horses that had completed a race of $90-120 \mathrm{~km}$ in a time-course experimental design.

Conclusion: These results suggest that MMP-I and IL-8 are both involved in the exercise-induced stress response, and this represents a starting point from which to understand the adaptive responses to this phenomenon.
\end{abstract}

\section{Background}

It is widely accepted that moderate physical activity may have beneficial effects on the overall health of humans and other animals, while strenuous physical effort induces an inflammation-like state, whose grade depends on the type, intensity and duration of the activity $[1,2]$. The molecular mechanisms that underlie the cellular response to this phenomenon are still unclear; however, it is well known that it involves the coordinated action of multiple organ systems. The process begins with disruption of the homeostasis of the neuroendocrine-immune system, which alters the concentrations of neurotransmit- ters, hormones and cytokines. Exercise is followed by an intensity-dependent increase in sympathetic activity, which involves activation of the hypothalamus-pituitary axis. This leads to systemic secretion of catecholamines, which influence various immunological processes, including lymphocyte proliferation and differentiation, and production of cytokines $[3,4]$. Knowledge of the molecular mechanism of acute exercise-induced stress is a fundamental prerequisite for the planning of appropriate training schedules to improve the performance and maintain the welfare of the athlete. 
Like a human marathon runner, the endurance horse undergoes extreme effort and can be considered a good model for the study of exercise-induced stress.

Given that exercise has been shown to be an important factor in the regulation of immune cells and their functions, and considering that stress evokes inflammatory reactions, peripheral blood mononuclear cells (PBMCs) are thought to be the best cell type in which to investigate the physiological changes associated with strenuous exercise [5]. Changes in the expression of a group of genes within the leukocytes may serve as surrogate markers for systemic or local modifications induced by exercise, and thus obviate the need for muscle biopsies [6].

The response of leukocytes to physical exercise, which involves the expression of multiple genes, is well known. Nevertheless, we are far from having a complete list of genes that are differentially expressed and, above all, far from a deep understanding of the regulatory mechanisms involved.

Analysis of leukocytes using microarrays has allowed the changes in immune function associated with exercise to be better understood [5,7-11]. Despite these interesting findings, variations in methodological conditions (microarray platforms, heterogeneous cellular populations, etc.) make the comparison of the results of array analysis difficult. For example, a maximum of only 3 to 11 concordant genes were found to overlap in four different microarray analyses of leukocytes after exercise [12]. Another technique that can be applied to this phenomenon is CDNAAFLP [13]; this method allows novel genes to be identified without any previous sequence information. This is a robust and sensitive technology with low start-up costs that is used for discovery of genes on the basis of fragment detection [14].

This technique of genome-wide expression analysis has been used to study exercise-induced stress in endurance horses. It allowed us to identify, among a large set of genes, two transcript-derived fragments that were differentially expressed: one (FG341843) encoding metalloproteinase 1 (MMP-1) and one (CO508730) encoding interleukin $8(I L-8)$.

Metalloproteinases (MMPs) and chemokines, which are induced by the inflammatory response, are involved in the redistribution of lymphocytes between lymphoid and non-lymphoid organs and the mobilization of haematopoietic progenitor cells (HPCs) from bone marrow. These processes have been shown recently to be related to exercise-induced stress $[5,15,16]$. The major chemokine that is able to increase the number of mobilized HPCs is IL- 8 , and this chemokine also stimulates the production of MMPs. Matrix metalloproteinase-1 is involved in the enhanced peripheral invasion and migration into tissues of natural killer (NK) cells in humans. Production of MMP-1 from stimulated NK cells plays a role in the facilitation of lymphocyte trafficking, and in the accumulation of lymphocytes in tissues during physiological and pathological processes [17].

The aim of this study was to investigate the expression of IL-8 and MMP-1, which had been identified with a gene discovery technique [18], in equine athletes. In addition, with the use of data from previously published reports, we wished to determine the possible role of these genes in acute exercise-induced stress.

To achieve this goal, we used quantitative real-time PCR (qRT-PCR), which is the technique of choice to detect modifications in the level of transcription of specific genes in a reliable and reproducible manner.

\section{Results}

The raw cycle threshold values (Cts) detected during qRTPCR experiments by MxPro software 3.21 (Stratagene) were analysed using the software GenEx Pro [19]. This allowed the results of the real-time PCR to be analysed using two reference genes (SDHA, HPRT), with which the expression levels of the genes of interest were compared. This approach produces more consistent data in comparison with those obtained using only one reference gene $[20,19]$.

During the pre-processing phase, data were corrected for the efficiency of the PCR (Table 1) and were averaged over the three technical repeats (considering only results that showed a standard deviation less than 0.2 within the triplicate). The selected reference genes HPRT and SDHA were used subsequently to normalize the $\mathrm{Ct}$ values, and the relative quantities were calculated on the basis of the maximum $\mathrm{Ct}$ value. Given our interest in the changes in the expression of genes between samples, the quantities were finally converted to a logarithmic scale using a log base 2 conversion. Changes in the relative expression of the genes encoding IL-8 and MMP-1 were checked for statistical significance using a non-linear mixed-effects model for repeated data using the nlme library from $\mathrm{R}$ [21], using version 2.7.2 of the software $\mathrm{R}$. The resulting bar chart (Figure 1) shows an up-regulation $(2.74 \times$ for $I L-8, P<$ $0.001 ; 5 \times$ for MMP-1, $P<0.001-\log$ base 2 induction) immediately after the race, and a non-significant difference between basal and 24 hours values (IL-8 P $=0.1464$, MMP-1 $P=0.3689$ ). These results demonstrate a significant up-regulation of MMP-1 and $I L-8$ induced by exercise in the PBMC of endurance horse in an in vivo system with a consistent number of animals. 


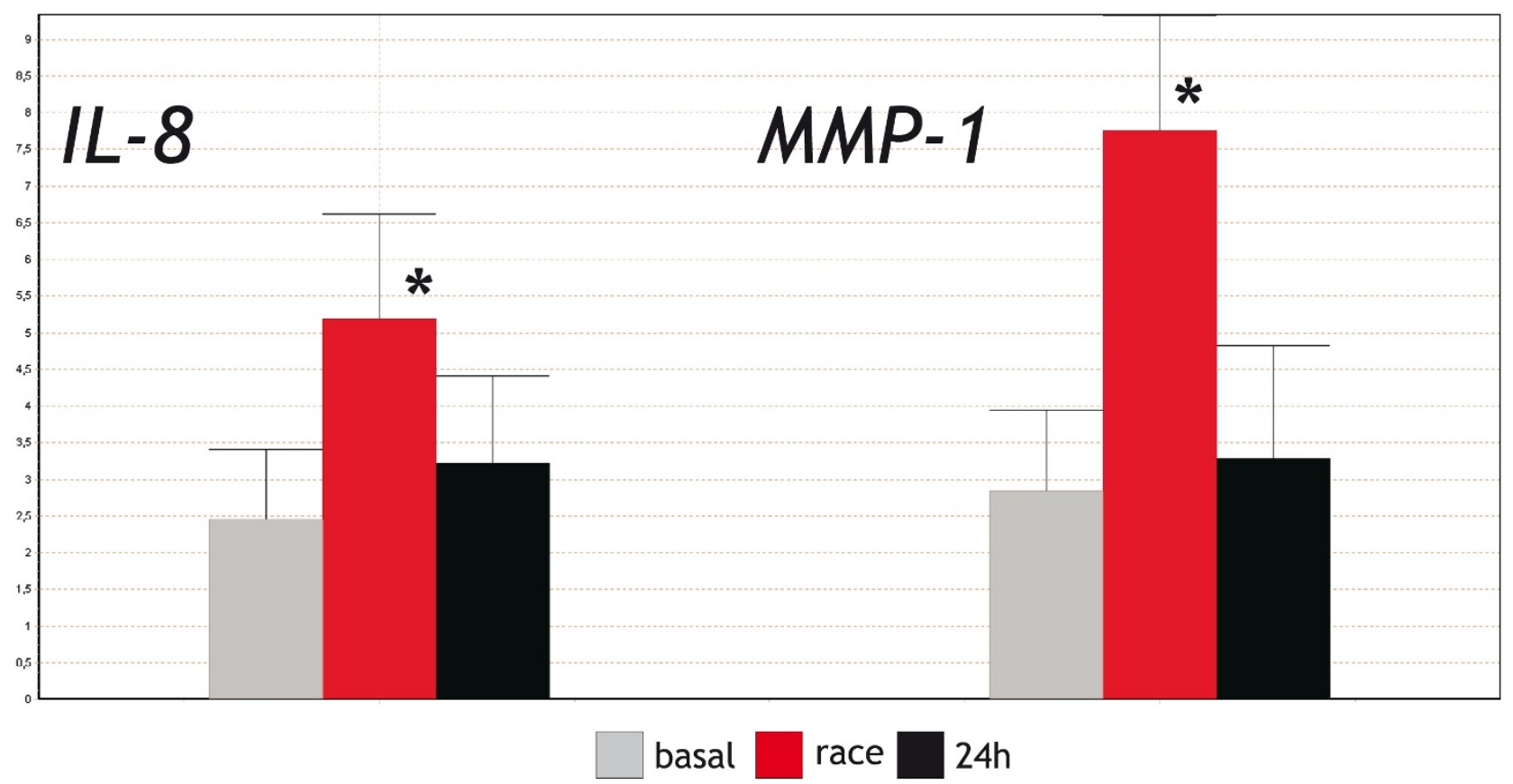

Figure I

Relative expression bar chart. Bar chart of expression of IL-8 and MMP- $I$ in $I 0$ endurance horses during a time course experiment (basal, race, $24 \mathrm{~h}$ ). Error bars indicate the $95 \%$ confidence interval. Relative expression values are on a logarithmic base 2 scale. Asterisks indicate significance at $P<0.00 \mathrm{I}$.

In addition, the Pearson's correlation coefficient calculated between the level of expression of $I L-8$ and that of MMP-1 $(\rho=0.74)$ showed a strong relationship between the two genes.

\section{Discussion}

In the present study, transcripts of MMP-1 and $I L-8$ were found to be strongly up-regulated during an equine endurance exercise and to be down-regulated 24 hours after the effort, which suggests a role for these genes in exercise-induced stress.

Matrix metalloproteinase- 1 is a member of a large family of calcium-dependent zinc-containing endopeptidases,
MMPs, which are responsible for tissue remodelling and degradation of the extracellular matrix (ECM) $[22,23]$. The expression of MMP-1 is stimulated at the transcriptional level by growth factors and cytokines $[24,25]$.

The MMPs are secreted by connective tissues and by proinflammatory cells, including fibroblasts, osteoblasts, endothelial cells, macrophages, neutrophils and lymphocytes [23].

Interleukin 8 is a prototypical chemokine, and its most remarkable property is the wide variation in its level of expression in response to cellular stress. IL-8 is known to be produced by monocytes and macrophages, as well as

Table I: Real-time PCR primer pairs and assay conditions.

\begin{tabular}{|c|c|c|c|c|c|}
\hline Gene & Accession number & Primers (forward, reverse) & Amplicon length, bp & Efficiency of assay, \% & $r^{2}$ \\
\hline MMP-I & NM 001081847 & $\begin{array}{l}\text { CTGCTGCTGCTGCCACTC } \\
\text { TCTCCATCACTCTTCAGGTTGTAG }\end{array}$ & $|3|$ & 100.8 & 1.000 \\
\hline IL-8 & NM 00108395I & $\begin{array}{l}\text { CTGGCTGTGGCTCTCTTG } \\
\text { CAGTTTGGGATTGAAAGGTTTG }\end{array}$ & 132 & 97.8 & 0.999 \\
\hline HPRT & AY372182 & $\begin{array}{l}\text { AATTATGGACAGGACTGAACGG } \\
\text { ATAATCCAGCAGGTCAGCAAAG }\end{array}$ & 121 & 93.9 & 1.000 \\
\hline SDHA & DQ402987 & $\begin{array}{l}\text { GAGGAATGGTCTGGAATACTG } \\
\text { GCCTCTGCTCCATAAATCG }\end{array}$ & 91 & 96.0 & 0.999 \\
\hline
\end{tabular}


by most tissues, and its secretion is induced by a number of stimuli, including pro-inflammatory cytokines $[26,27]$. The plasma concentration of IL-8 increases in response to strenuous exercise that is comprised of both eccentric and concentric components, such as running, and the regulation of $I L-8$ production occurs mainly at the level of transcription [28].

An attractive hypothesis concerning the role of MMP-1 and $I L-8$ in the response of PBMCs to physical stress is their involvement in lymphocyte trafficking and in the recruitment of progenitor stem cells from bone marrow.

Recent studies have shown that redistribution of leukocytes is a fundamental regulatory mechanism of the haematopoietic system that alters lymphocyte counts during exercise [15], as was observed in our samples obtained immediately after the race (data not shown). The ability of immune cells to migrate appears to be closely regulated by molecules such as chemokines and proteinases, and is mediated through receptors of the integrin family [29]. Cytokines stimulate the expression of multiple MMPs from lymphocytes. Recent studies suggest that MMP-1, produced by chemokine-stimulated NK cells, could play a role in the traversal of tissues by promoting the degradation of matrix collagens as well as by processing chemokines. Although the exact mechanism by which lymphocytes invade tissues is not completely understood, this migration seems to be regulated by distinct pathways that involve mitogen-activated protein kinases (MAPKs). Goda and colleagues [17] demonstrated that MMP-1 is produced by chemokine-stimulated NK cells and that it associates with $\alpha_{2} \beta_{1}$ integrin, which suggests that integrins play a role in the immobilization of MMP-1 on the cell surface. The binding of MMPs to integrins would be a critical step for promoting lymphocyte migration, given that the disruption of this association decreases the migratory ability of cells [30]. It is also known that integrins are involved in the signalling pathway of the Rho family of GTPases that has been associated recently with modulation of the expression of $I L-8$ and MMP-1. When one of these key GTPases, Cdc42, is silenced, over-expression of $I L-8$ and MMP-1 is induced by inhibition of the ERK1/2 pathway [29].

In addition to the redistribution of lymphocytes, exercise is accompanied by the recruitment of stem cells and progenitor cells from the bone marrow [16]. Cytokines can increase the number of mobilized haematopoietic progenitor cells (HPCs) by releasing proteinases, and it has been demonstrated that IL-8 is the chemokine that shows the most rapid mobilization of HPCs in monkeys and mice [31]. IL-8 is also chemotactic for neutrophils and induces the release of metalloproteinases. The most commonly accepted hypothesis is that MMP-9, secreted by neutrophils, is required for the recruitment of HPCs [32]. However, unexpectedly, mice deficient in MMP-9 exhibited normal mobilization of HPCs, which suggests the existence of redundant pathways that compensate for the lack of this protease [33]. Our results, in addition to these previous findings, allow us to hypothesize that MMP-1 is part of this redundant pathway in PBMCs, and that it plays an important role in the mobilization of HCPs. This hypothesis is also supported by the over-expression of $I L$ 8 that was observed in the 10 horses used in this work; IL8 is considered to be a key chemokine in the mobilization of HCPs [31].

Moreover, our data confirm that there is a strong correlation between the up-regulation of MMP-1 and that of $I L$ 8 . The reason for the co-expression of MMP-1 and $I L-8$ in response to various stimuli, such as exercise-induced stress, could be found in their shared pathways and interactions with messenger molecules that are involved in the inflammatory and immune response.

\section{Conclusion}

A significant co-induction of the MMP-1 and $I L-8$ genes was found, using a robust qRT-PCR approach, to occur immediately after strenuous exercise in PBMCs from 10 endurance horses. The quantitative method used in this study underlines the results obtained with genome-wide expression analysis, which was used to explore the in vivo stress system. Even if the induction of mRNA is not ever followed by an increase in the related protein and its activity, these results, together with evidence from the literature, suggest that IL- 8 and MMP-1 are involved in the adaptation to exercise-induced stress and that they may have a role in lymphocyte trafficking and in the recruitment of progenitor stem cells from the bone marrow. Further evidence, such as proteomic data and the results of studies of cell mobilization tracking, will be required to confirm our findings.

\section{Methods}

\section{Blood collection, RNA extraction and CDNA synthesis}

Blood samples were taken from the jugular veins of horses chosen from the high-level participants in national and international endurance races $(90-120 \mathrm{~km})$. The samples were obtained at three different time points: before (basal), at the end of the race (race), and 24 hours after the race $(24 h)$. Only horses that passed the FISE (Italian Equestrian Sports Federation) compulsory medical checks (pre, during and post-race) were considered suitable for this study. Ten endurance horses, comparable for training type and intensity, were recruited. The medical checks consisted of an examination of cardio-respiratory function, physical integrity, and metabolic condition, together with collection of a blood sample for a complete blood count. 
The animals involved in this study were treated following standard procedures to ensure animal welfare, in agreement with the horse owners, team veterinarian and the official veterinary commission.

Immediately after collection of blood, peripheral blood mononuclear cells (PBMCs) were isolated by the FicollHypaque method (GE Healthcare, Pollards Wood, UK). Total RNA was extracted using the Aurum Total RNA Fatty and Fibrous Tissue kit (Bio-Rad, Hercules, CA, USA) according to the manufacturer's instructions. Genomic DNA was eliminated by a DNase treatment supplied with the kit. The extracted RNA was quantified using the Quant-It RNA assay (Invitrogen, Dorset, UK) in a VersaFluor fluorometer (Bio-Rad) and checked for integrity by denaturing agarose gel electrophoresis with ethidium bromide staining. Successful removal of DNA contaminants was tested by determining the absence of PCR amplification of the MC1R gene (GenBank accession number X98012, primers from Rieder and colleagues) [34]. Total RNA $(1 \mu \mathrm{g})$ was retro-transcribed using random examers and Superscript III Reverse Transcriptase (Invitrogen) according to the manufacturer's specifications. A PCR for the Equus caballus $\beta$-actin gene (Forward 5'-GAGCAAGAGGGGCATCCTGA-3', Reverse 5'-GGTCATCTTCTCGCGGTTGG-3', Gene ID: 100033878) was performed on each sample of cDNA to check for successful retro-transcription.

\section{Reference gene selection and primer design}

The genes encoding succinate dehydrogenase complex subunit 1 (SDHA) and hypoxanthine phosphoribosyl transferase (HPRT), which were the best house-keeping genes selected from a group of nine potential genes, were utilized to estimate gene expression accurately during exercise-induced stress in horses [35].

The primers were designed based on available sequences (Table 1) using Primer3 software [36]. Mfold [37] was used to check the chosen sequences to avoid designing primers in the region of the template secondary structure, and the primers were located, when possible, on different exons or at the exon-exon junction. The amplicon lengths ranged from 68 to $138 \mathrm{bp}$, to ensure optimal polymerization and efficiency. The specificity of target amplification was confirmed by sequencing.

For each primer pair, a preliminary real-time assay was performed to evaluate the amplification of non-specific products or primer dimer artefacts (no double peak in melt curve analysis). Efficiency was determined as follows: for each assay, a standard curve was generated by using 4-fold serial dilutions of pooled cDNAs. As showed in Table 1, linear correlation coefficients $\left(\mathrm{r}^{2}\right)$ varied from
0.999 to 1.000 and PCR efficiencies (e) ranged between 93.9 and $100.8 \%$.

\section{Real-time quantitative PCR}

Five microliters of cDNA template (previously diluted 1:10) were added to the master mix FastStart SYBR Green Master (Roche Applied Science, Penzberg, Germany) with the ROX fluorochrome internal check. The PCR was performed in a volume of $25 \mu \mathrm{l}$ on a MX3000P instrument (Stratagene, La Jolla, CA, USA). The PCR conditions were the same for all primer pairs: initial denaturation at $95^{\circ} \mathrm{C}$ for $10 \mathrm{~min}$, followed by 40 cycles of denaturation at $95^{\circ} \mathrm{C}$ for $30 \mathrm{sec}$, annealing at $58^{\circ} \mathrm{C}$ for $30 \mathrm{sec}$ and extension at $72^{\circ} \mathrm{C}$ for $30 \mathrm{sec}$. Fluorescence data were collected at the end of the extension step. Following cycling, the melting curve was determined in the range $58^{\circ}-95^{\circ} \mathrm{C}$, with a temperature increment of $0.01^{\circ} \mathrm{C} / \mathrm{sec}$. Each reaction was run in triplicate with appropriate negative controls.

Raw Ct from the MX3000P instrument were exported to a common exchange data file and analysed using GeneEx Pro [19] in order to correct the data against the two housekeeping genes and to calculate the Pearson correlation coefficient between the expression of $I L-8$ and that of $M M P-1$. The software R [21] was used to perform analysis of variance (ANOVA) with a non-linear mixed-effects model.

\section{Authors' contributions}

KC drafted the manuscript and performed all experiments with MF. SC helped in drafting the manuscript and performed data analysis with CP's supervision. MS conceived the project, and AVS supervised and coordinated the project and participated in writing the manuscript. All authors read and approved the final manuscript.

\section{Acknowledgements}

The authors thank Mr Gianluca Alunni for his valuable technical support. Special thanks go to Sister Mary Trainor for revision of the English language. The authors are also grateful to Dr Alessandro Centinaio, Dr Marcello Conte, Miss Chiara Rosi and Mr Carlo Formica for allowing the samples to be collected.

This work was supported by MIUR - PRIN 2006 (coordinator Prof. Maurizio Silvestrelli).

\section{References}

I. Hoffman-Goetz L, Spagnuolo P, Guan J: Repeated exercise in mice alters expression of IL- 10 and TNF-[alpha] in intestinal lymphocytes. Brain Behav Immun 2008, 22:195-199.

2. Pedersen BK: IL-6 signalling in exercise and disease. Biochem Soc Trans 2007, 35:I295-7.

3. Ottaviani E, Franceschi C: The neuroimmunology of stress from invertebrates to man. Prog Neurobiol 1996, 48:421-40.

4. Sanders JM, Ghosh S, Chan JMW, Meints G, Wang H, Raker AM, Song Y, Colantino A, Burzynska A, Kafarski P, Morita CT, Oldfield E: Quantitative structure-activity relationships for gammadelta $\mathbf{T}$ cell activation by bisphosphonates. J Med Chem 2004, 47:375-84. 
5. Buttner P, Mosig S, Lechtermann A, Funke H, Mooren F: Exercise affects the gene expression profiles of human white blood cells. J Appl Physiol 2007, 102:26-36.

6. Zeibig J, Karlic H, Lohninger A, Dumsgaard R, Smekal G: Do blood cells mimic gene expression profile alterations known to occur in muscular adaptation to endurance training? Eur J Appl Physiol 2005, 95:96-104.

7. Connolly P, Caiozzo V, Zaldivar F, Nemet D, Larson J, Hung S, Heck J, Hatfield G, Cooper D: Effects of exercise on gene expression in human peripheral blood mononuclear cells. J Appl Physiol 2004, 97:146I-I 469 .

8. Zieker D, Zieker J, Dietzsch J, Burnet M, Northoff H, Fehrenbach E: CDNA-microarray analysis as a research tool for expression profiling in human peripheral blood following exercise. Exerc Immunol Rev 2005, I I:86-96.

9. Hilberg T, Deigner H, Möller E, Claus RA, Ruryk A, Gläser D, Landre J, Brunkhorst FM, Reinhart K, Gabriel HHW, Russwurm S: Transcription in response to physical stress-clues to the molecular mechanisms of exercise-induced asthma. FASEB J 2005, 19:|492-4.

10. Barrey E, Mucher E, Robert C, Amiot F, Gidrol X: Gene expression profiling in blood cells of endurance horses completing competition or disqualified due to metabolic disorder. Equine Vet J Suppl 2006, 36:43-49.

II. Sonna LA, Sawka MN, Lilly CM: Exertional heat illness and human gene expression. Prog Brain Res 2007, 162:321-46.

12. Fehrenbach E: Multifarious microarray-based gene expression patterns in response to exercise. J Appl Physiol 2007, I02:7-8.

13. Bachem CW, Hoeven RS van der, de Bruijn SM, Vreugdenhil D, Zabeau M, Visser RG: Visualization of differential gene expression using a novel method of RNA fingerprinting based on AFLP: Analysis of gene expression during potato tuber development. Plant J 1996, 9:745-753.

14. Vuylsteke M, Peleman JD, van Eijk MJT: AFLP-based transcript profiling (cDNA-AFLP) for genome-wide expression analysis. Nat Protoc 2007, 2:1399-413.

15. Krüger K, Mooren FC: T cell homing and exercise. Exerc Immunol Rev 2007, I 3:37-54.

16. Morici G, Zangla D, Santoro A, Pelosi E, Petrucci E, Gioia M, Bonanno A, Profita M, Bellia V, Testa U, Bonsignore MR: Supramaximal exercise mobilizes hematopoietic progenitors and reticulocytes in athletes. Am J Physiol Regul Integr Comp Physiol 2005, 289:RI496-I503.

17. Goda S, Inoue H, Umehara H, Miyaji M, Nagano Y, Harakawa N, Imai $\mathrm{H}$, Lee P, MaCarthy JB, Ikeo T, Domae N, Shimizu Y, lida J: Matrix Metalloproteinase-I Produced by Human CXCLI 2-Stimulated Natural Killer Cells. Am J Pathol 2006, 169:445-458.

18. Cappelli K, Verini-Supplizi A, Capomaccio S, Silvestrelli M: Analysis of peripheral blood mononuclear cells gene expression in endurance horses by cDNA-AFLP technique. Res Vet Sci 2007, 82:335-43

19. Kubista M, Andrade JM, Bengtsson M, Forootan A, Jonák J, Lind K, Sindelka R, Sjöback R, Sjögreen B, Strömbom L, Ståhlberg A, Zoric N: The real-time polymerase chain reaction. Mol Aspects Med 2006, 27:95-125

20. Vandesompele J, De Preter K, Pattyn F, Poppe B, Van Roy N, De Paepe A, Speleman F: Accurate normalization of real-time quantitative RT-PCR data by geometric averaging of multiple internal control genes. Genome Biol 2002, 3:research0034. I-research0034.II.

21. R Development Core Team: R: A language and environment for statistical computing. 2008 [http://www.r-project.org]. R Foundation for Statistical Computing Vienna, Austria

22. Sampieri CL, Nuttall RK, Young DA, Goldspink D, Clark IM, Edwards DR: Activation of $\mathrm{p} 38$ and JNK MAPK pathways abrogates requirement for new protein synthesis for phorbol ester mediated induction of select MMP and TIMP genes. Matrix Biol 2008, 27: 128-138.

23. Verma RP, Hansch C: Matrix metalloproteinases (MMPs): Chemical-biological functions and (Q)SARs. Bioorgan Med Chem 2007, 15:2223-2268.

24. Boyd S, Kalle T, Susanna V, Tiina K, Lauri K, Saarialho-Kere U: Differential expression of stromal MMP-I, MMP-9 and TIMP-I in basal cell carcinomas of immunosuppressed patients and controls. Virchows Arch 2008, 452:83-90.
25. Westermarck J, Seth A, Kähäri VM: Differential regulation of interstitial collagenase (MMP-I) gene expression by ETS transcription factors. Oncogene 1997, 14:265 I-60.

26. Baggiolini M, Dewald B, Moser B: Interleukin-8 and related chemotactic cytokines-CXC and CC chemokines. Adv Immunol 1994, 55:97-179.

27. Hoffmann E, Dittrich-Breiholz O, Holtmann H, Kracht M: Multiple control of interleukin-8 gene expression. J Leukoc Biol 2002, 72:847-55.

28. Yang $\mathrm{H}$, Cohen $\mathrm{P}$, Rousseau S: IL-I beta-stimulated activation of ERK I/2 and p38alpha MAPK mediates the transcriptional up-regulation of IL-6, IL-8 and GRO-alpha in HeLa cells. Cell Signal 2008, 20:375-80.

29. Deroanne CF, Hamelryckx D, Ho TTG, Lambert CA, Catroux P, Lapière CM, Nusgens BV: Cdc42 downregulates MMP-I expression by inhibiting the ERKI/2 pathway. J Cell Sci 2005, I 18:1 173-83.

30. Stefanidakis M, Bjorklund M, Ihanus E, Gahmberg CG, Koivunen E: Identification of a negatively charged peptide motif within the catalytic domain of progelatinases that mediates binding to leukocyte beta 2 integrins. I Biol Chem 2003, 278:34674-84.

31. Laterveer L, Zijlmans JM, Lindley IJ, Hamilton MS, Willemze R, Fibbe WE: Improved survival of lethally irradiated recipient mice transplanted with circulating progenitor cells mobilized by IL-8 after pretreatment with stem cell factor. Exp Hematol 1996, 24:1387-93.

32. Fibbe WE, Pruijt JF, Velders GA, Opdenakker G, van Kooyk Y, Figdor CG, Willemze R: Biology of IL-8-induced stem cell mobilization. Ann N Y Acad Sci 1999, 872:71-82.

33. Velders GA, Fibbe WE: Involvement of proteases in cytokineinduced hematopoietic stem cell mobilization. Ann $N$ Y Acad Sci 2005, 1 044:60-9.

34. Rieder $S$, Taourit $S$, Mariat $D$, Langlois $B$, Guérin G: Mutations in the agouti (ASIP), the extension (MCIR), and the brown (TYRPI) loci and their association to coat color phenotypes in horses (Equus caballus). Mamm Genome 200 I, I 2:450-455.

35. Cappelli K, Felicetti M, Capomaccio S, Spinsanti G, Silvestrelli M, Supplizi A: Exercise induced stress in horses: Selection of the most stable reference genes for quantitative RT-PCR normalization. BMC Mol Biol 2008, 9:49.

36. Rozen S, Skaletsky H: Primer3 on the WWW for general users and for biologist programmers. Methods Mol Biol 2000, 132:365-86

37. Zuker M: Mfold web server for nucleic acid folding and hybridization prediction. Nucleic Acids Res 2003, 3 I:3406-34I5.

Publish with Bio Med Central and every scientist can read your work free of charge

"BioMed Central will be the most significant development for disseminating the results of biomedical research in our lifetime. "

Sir Paul Nurse, Cancer Research UK

Your research papers will be:

- available free of charge to the entire biomedical community

- peer reviewed and published immediately upon acceptance

- cited in PubMed and archived on PubMed Centra

- yours - you keep the copyright 